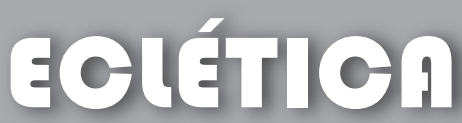 química
}

\section{THERMAL BEHAVIOUR OF SUCCINIC ACID, SODIUM SUCCINATE AND ITS COMPOUNDS WITH SOME BIVALENT TRANSITIONS METAL IONS IN DYNAMIC $\mathbf{N}_{2}$ AND $\mathrm{CO}_{2}$ ATMOSPHERES}

\author{
CF. J. Caires, L. S. Lima, C. T. Carvalho, M. Ionashiro ${ }^{I}$ \\ Instituto de Química, Universidade Estadual Paulista, CP 355, 14801-970 Araraquara, SP, Brazil. \\ ${ }^{1}$ Corresponding author. Tel. +55-16-3301-6617; Fax: +55-16-3301-6692 \\ E-mail address:massaoi@yahoo.com.br
}

\begin{abstract}
Thermal stability and thermal decomposition of succinic acid, sodium succinate and its compounds with $\mathrm{Mn}(\mathrm{II}), \mathrm{Fe}(\mathrm{II}), \mathrm{Co}(\mathrm{II}), \mathrm{Ni}(\mathrm{II}), \mathrm{Cu}(\mathrm{II})$ and $\mathrm{Zn}(\mathrm{II})$ were investigated employing simultaneous thermogravimetry and differential thermal analysis (TG-DTA) in nitrogen and carbon dioxide atmospheres and TG-FTIR in nitrogen atmosphere. On heating, in both atmospheres the succinic acid melt and evaporate, while for the sodium succinate the thermal decomposition occurs with the formation of sodium carbonate. For the transition metal succinates the final residue up to $1180^{\circ} \mathrm{C}$ in $\mathrm{N}_{2}$ atmosphere was a mixture of metal and metal oxide in no simple stoichiometric relation, except for $\mathrm{Zn}$ compound, where the residue was a small quantity of carbonaceous residue. For the $\mathrm{CO}_{2}$ atmosphere the final residue up to $980{ }^{\circ} \mathrm{C}$ was: $\mathrm{MnO}, \mathrm{Fe}_{3} \mathrm{O}_{4}, \mathrm{CoO}, \mathrm{ZnO}$ and mixtures of $\mathrm{Ni}, \mathrm{NiO}$ and $\mathrm{Cu}, \mathrm{Cu}_{2} \mathrm{O}$.
\end{abstract}

Keywords: bivalent transitions metals, succinate, thermal behavior.

\section{Introduction}

Preparation and investigation on the thermal behaviour and thermal decomposition of several metal-ion succinates have been reported. These papers are concerned with the thermal decomposition of bivalent succinates in the solid state [1], the thermal, spectral and magnetic studies of succinic acid and compounds of some transition metal ions [2], thermal dehydration of manganese (II) dicarboxylate hydrates [3], synthesis, properties and thermal decomposition of $\mathrm{Co}(\mathrm{II}), \mathrm{Ni}(\mathrm{II}), \mathrm{Cu}(\mathrm{II}), \mathrm{Zn}(\mathrm{II})$ and $\mathrm{Cd}(\mathrm{II})$ succinates [4], a study of the thermal decomposition of $\mathrm{Cu}(\mathrm{II})$ and $\mathrm{Zn}$ (II) malonate, maleate and succinate complex [5] and a comparative study on the thermal decomposition of some transition metal carboxylates [6]. As continuation of our previous study on thermal behavior of succinic acid, sodium succinate and its compounds with some bivalent transition metal ions in air atmosphere [7], this paper deals with the thermal behavior and thermal decomposition of these compounds in dynamic $\mathrm{N}_{2}$ and $\mathrm{CO}_{2}$ atmospheres.

\section{Experimental}

The succinic acid $\mathrm{C}_{4} \mathrm{H}_{6} \mathrm{O}_{4}$, and its sodium salt $\mathrm{Na}_{2} \mathrm{C}_{4} \mathrm{H}_{4} \mathrm{O}_{4} \cdot 6 \mathrm{H}_{2} \mathrm{O}$, both with $99 \%$ purity were obtained from Sigma.

Solid state $\mathrm{Mn}$ (II), $\mathrm{Fe}(\mathrm{II}), \mathrm{Co}(\mathrm{II}), \mathrm{Ni}(\mathrm{II}), \mathrm{Cu}(\mathrm{II})$ and $\mathrm{Zn}(\mathrm{II})$ compounds were prepared by mixing the aqueous suspension of the corresponding metal carbonates in excess with $50.0 \mathrm{~mL}$ of succinic acid $0.10 \mathrm{~mol} \mathrm{~L}^{-1}$ solution, and heated slowly up to near 
ebullition, until total neutralization of the acid. The carbonate in excess was removed by filtration and the aqueous solution of the respective metal succinates were evaporated to near dryness in a water bath, dried in air and kept in a desiccator over anhydrous calcium chloride. To avoid the oxidation of Fe(II), all the solutions, as well as in the evaporation of the solution in water bath were purged with nitrogen gas.

In the solid-state compounds, metal ions, hydration water and succinate contents were determined from TG curves. The metal ions were also determined by complexometry with standard EDTA solution, after igniting the compounds to the respective oxides and their dissolution in hydrochloric acid solution [8].

Carbon and hydrogen contents were determined by microanalytical procedures, with an EA 1110 CHNS-O Elemental Analyser from CE Instruments.

Simultaneous TG-DTA curves were obtained with the thermal analysis system, model SDT 2960 from TA Instruments. The purge gases were nitrogen and carbon dioxide flow of $100 \mathrm{~mL} \mathrm{~min}^{-1}$. A heating rate of $20^{\circ} \mathrm{C} \mathrm{min}^{-1}$ was adopted, with sample weighing about $7 \mathrm{mg}$ and alumina crucible was used for recording the TG-DTA curves.

The measurements of the gaseous products were carried out using a Thermogravimetric Analyzer Mettler TG-DTA coupled to a FTIR spectrophotometer Nicolet is10, with gas cell and DTGS KBr detector. The furnace and the heated gas cell $\left(250^{\circ} \mathrm{C}\right)$ were coupled through a heated $(\mathrm{T}=$ $\left.200^{\circ} \mathrm{C}\right) 120 \mathrm{~cm}$ stainless steel line transfer with diameter of $2 \mathrm{~mm}$, both purged with dry nitrogen (50 $\left.\mathrm{mL} \mathrm{min}^{-1}\right)$. The FTIR spectra were recorded with 32 scans per spectrum at a resolution of $4 \mathrm{~cm}^{-1}$.

\section{Results and Discussion}

\section{Succinic acid}

The TG-DTA curves and infrared spectrum of the released product during the heating of succinic acid in $\mathrm{N}_{2}$ and $\mathrm{CO}_{2}$ atmospheres are shown in Fig. 1. The TG-DTA curves, Fig 1a and $1 \mathrm{~b}$ show mass loss in single step between 165 and $260^{\circ} \mathrm{C}\left(\mathrm{N}_{2}, \mathrm{CO}_{2}\right)$ corresponding to the endothermic peaks at 194 and $247^{\circ} \mathrm{C}\left(\mathrm{N}_{2}\right)$ or 194 and $250^{\circ} \mathrm{C}\left(\mathrm{CO}_{2}\right)$, attributed to the fusion and evaporation of succinic acid, respectively. The product evaporated was monitored and identified mostly on base of their FTIR reference available on Nicolet libraries, as shown in Fig. 1c.
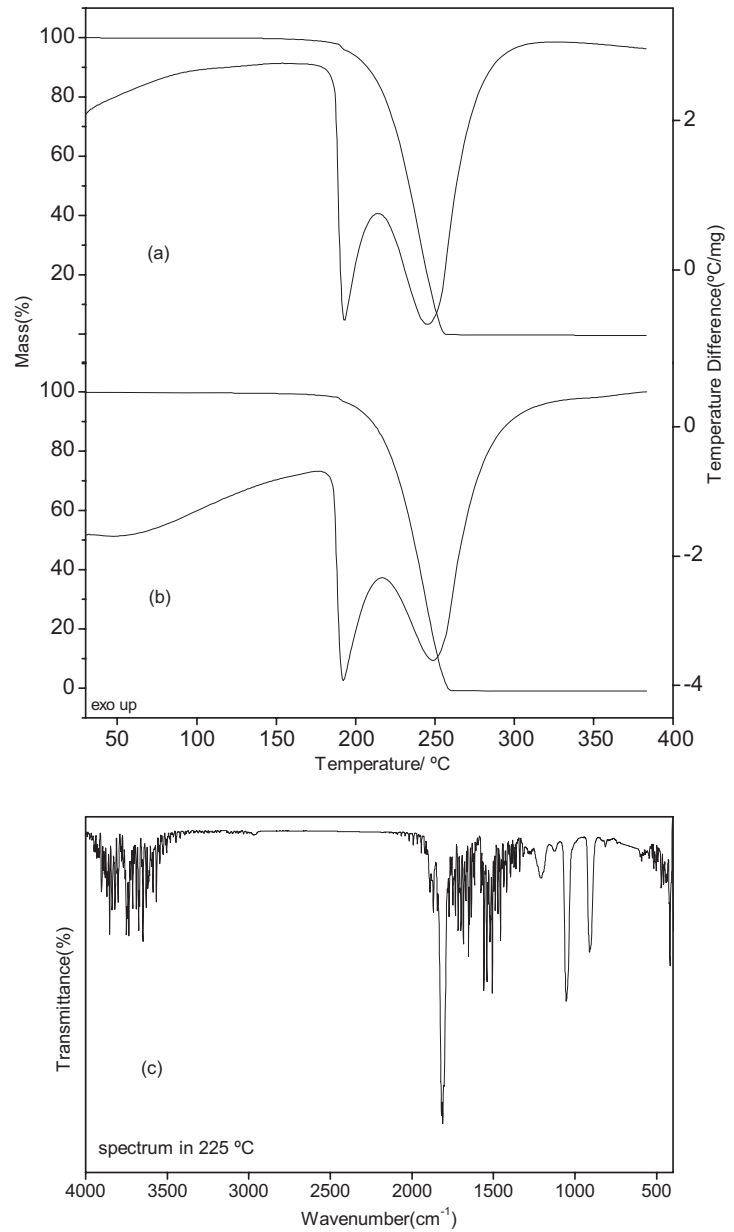

Figure 1. Simultaneous TG-DTA curves in dynamic (a) $\mathrm{N}_{2}$ (m = $7.326 \mathrm{mg}$ ), (b) $\mathrm{Co}_{2}(7.359 \mathrm{mg}$ ) atmospheres and (c) IR spectrum of the gases released during the decomposition of succinic acid in $\mathrm{N}_{2}$ atmosphere.

\section{Sodium Succinate hexahydrated}

For the sodium succinate hexahydrated, the TGDTA curves in $\mathrm{N}_{2}$ and $\mathrm{CO}_{2}$ atmospheres are shown in Fig. $2 \mathrm{a}$ and $2 \mathrm{~b}$, respectively. These curves show mass losses in two steps and thermal events corresponding to these losses or due to physical phenomenon. The first mass loss between $30-130^{\circ} \mathrm{C}\left(\mathrm{N}_{2}\right)$ and $30-150{ }^{\circ} \mathrm{C}$ $\left(\mathrm{CO}_{2}\right)$, corresponding to an endothermic peak at $85^{\circ} \mathrm{C}$ $\left(\mathrm{N}_{2}, \mathrm{CO}_{2}\right)$ is due to dehydration with loss of $6 \mathrm{H} 2 \mathrm{O}$ (Calcd. $40.02 \%$, TG $=39.86 \%\left(\mathrm{~N}_{2}\right), 40.20 \%\left(\mathrm{CO}_{2}\right)$ ). The endothermic peak at $410^{\circ} \mathrm{C}\left(\mathrm{N}_{2}, \mathrm{CO}_{2}\right)$, without mass loss in TG curve is due to fusion of the compound. In 


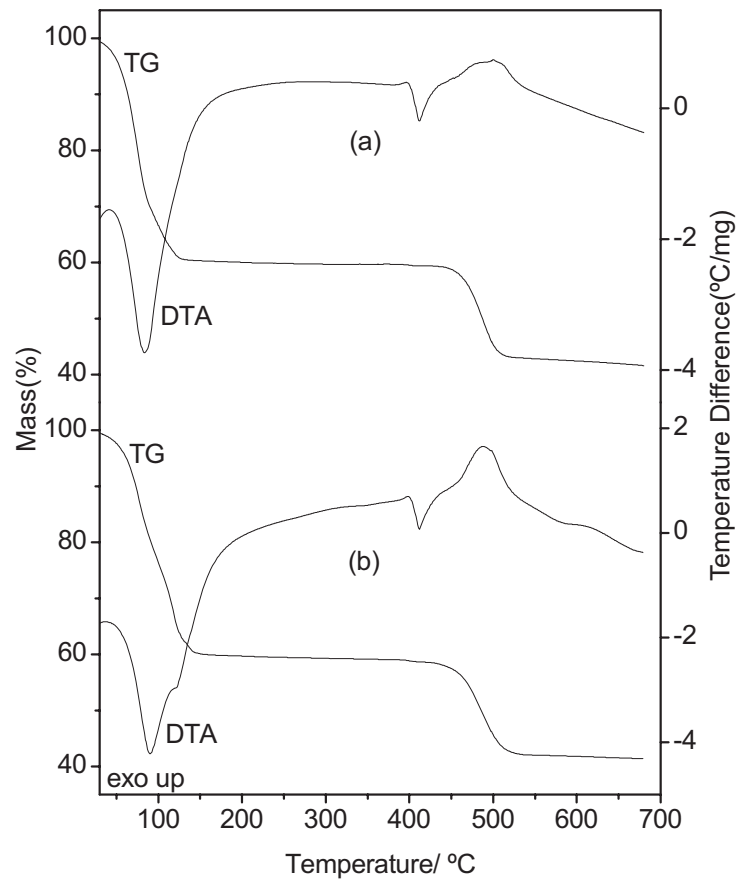

Figure 2. Simultaneous TG-DTA curves of the sodium succinate in (a) $\mathrm{N}_{2}(3.726 \mathrm{mg})$ and (b) $\mathrm{Co}_{2}$ (3.700 mg), atmospheres.

both atmospheres the anhydrous compound is stable up to $425^{\circ} \mathrm{C}$ and above this temperature the mass loss occurs between $425-525^{\circ} \mathrm{C}\left(\mathrm{N}_{2}\right)$ or $425-540{ }^{\circ} \mathrm{C}\left(\mathrm{CO}_{2}\right)$ with loss of $18.52 \%\left(\mathrm{~N}_{2}\right)$ and $18.42 \%\left(\mathrm{CO}_{2}\right)$, corresponding to the exothermic peak at $490{ }^{\circ} \mathrm{C}$ attributed to the decarboxylation with formation of sodium carbonate accompanied by carbonaceous residue.

\section{Transition metal succinates}

\section{TG-DTA Curves}

The analytical and thermoanalytical (TG) data for the synthesized compounds are shown in table 1. These results permitted to establish the stoichiometry of these compounds, which are in agreement with the general formula, $\mathrm{MC}_{4} \mathrm{H}_{4} \mathrm{O}_{4} \cdot \mathrm{nH}_{2} \mathrm{O}$, where $\mathrm{M}$ represents $\mathrm{Mn}(\mathrm{II}), \mathrm{Fe}(\mathrm{II}), \mathrm{Co}(\mathrm{II}), \mathrm{Ni}(\mathrm{II})$, $\mathrm{Cu}(\mathrm{II})$ and $\mathrm{Zn}(\mathrm{II}), \mathrm{C}_{4} \mathrm{H}_{4} \mathrm{O}_{4}$ is succinate and $\mathrm{n}=\mathrm{O}(\mathrm{Cu}$, $\mathrm{Zn}), 1(\mathrm{Fe}), 2(\mathrm{Mn}), 3(\mathrm{Co})$ or $3.5(\mathrm{Ni})$.

The simultaneous TG-DTA curves of these compounds obtained in $\mathrm{N}_{2}$ and $\mathrm{CO}_{2}$ atmospheres are shown in Fig. 3. These curves show mass losses or gain in two up to six steps, corresponding to endothermic peaks due to dehydration or pyrolysis of the anhydrous compounds and exothermic peaks attributed to physical phenomenon.

The thermal stability of the anhydrous compounds, in both atmospheres, as shown by the TG-DTA curves depend on the nature of the metal ion and they follow the order:

$$
\mathrm{Zn}>\mathrm{Co}>\mathrm{Ni}>\mathrm{Mn}>\mathrm{Cu}>\mathrm{Fe}
$$

For each compound a great similarity is observed concerning the TG-DTA profiles around $400^{\circ} \mathrm{C}$, in both atmospheres and above this temperature the thermal decomposition depend on the nature of the purge gas used and so the features of each of these compounds are discussed individually.

Manganese compound. The simultaneous TG-DTA curves in $\mathrm{N}_{2}$ and $\mathrm{CO}_{2}$ atmospheres are shown in Fig. $3 \mathrm{a}$ and $3 \mathrm{a}^{*}$, respectively. The first mass loss between 70 and $230^{\circ} \mathrm{C}$, corresponding to an endothermic peak at $110{ }^{\circ} \mathrm{C}$ in both atmospheres is due to the

Table 1. Analytical data for the $\mathrm{MC}_{4} \mathrm{H}_{4} \mathrm{O}_{4} \cdot \mathrm{nH}_{2} \mathrm{O}$ compounds.

\begin{tabular}{|c|c|c|c|c|c|c|c|c|c|c|c|c|}
\hline \multirow{2}{*}{ Compound } & \multicolumn{3}{|c|}{ Metal oxide (\%) } & \multicolumn{2}{|c|}{$\mathrm{L}($ lost $)(\%)$} & \multicolumn{2}{|c|}{$\mathrm{H}_{2} \mathrm{O}(\%)$} & \multicolumn{2}{|c|}{ C (\%) } & \multicolumn{2}{|c|}{$\mathrm{H}(\%)$} & \multirow{2}{*}{$\begin{array}{c}\text { Final } \\
\text { Residue }\end{array}$} \\
\hline & Calcd. & EDTA & $\mathrm{TG}^{*}$ & Calcd. & $\mathrm{TG}^{*}$ & Calcd. & $\mathrm{TG}^{*}$ & Calcd. & E.A. & Calcd. & E.A. & \\
\hline $\mathrm{MnL} \cdot 2 \mathrm{H}_{2} \mathrm{O}$ & 36.84 & 36.86 & 36.81 & 45.75 & 45.59 & 17.41 & 17.60 & 23.20 & 23.48 & 3.90 & 3.71 & $\mathrm{Mn}_{3} \mathrm{O}_{4}$ \\
\hline $\mathrm{FeL} \cdot \mathrm{H}_{2} \mathrm{O}$ & 42.04 & 41. & 4 & 48.47 & 48 & 9.49 & 030 & 25.29 & 56 & 3.19 & 3.10 & $\mathrm{Fe}_{2} \mathrm{O}_{3}$ \\
\hline $\mathrm{CoL} \cdot 3 \mathrm{H}_{2} \mathrm{O}$ & 35.0 & 34 & 34.94 & 41.3 & 41.71 & 23.60 & 23.35 & 20.97 & 21.15 & 4.41 & 4.37 & $\mathrm{Co}_{3} \mathrm{O}_{4}$ \\
\hline $\mathrm{NiL} \cdot 3 \mathrm{H}_{2} \mathrm{O}$ & 32.65 & 32.81 & 32.30 & 43.73 & 43.90 & 23.62 & 23.80 & 20.99 & 21.07 & 4.41 & 4.30 & $\mathrm{NiO}$ \\
\hline $\mathrm{CuL}$ & 44.29 & 43.94 & 43.94 & 55.71 & 56.06 & - & - & 26.74 & 26.51 & 2.25 & 2.11 & $\mathrm{CuO}$ \\
\hline $\mathrm{ZnL}$ & 44.84 & 45.13 & 44.65 & 55.16 & 55.35 & - & - & 26.48 & 26.67 & 2.23 & 2.35 & $\mathrm{ZnO}$ \\
\hline
\end{tabular}

$\mathrm{L}=$ succinate

*TG $=$ air atmosphere 

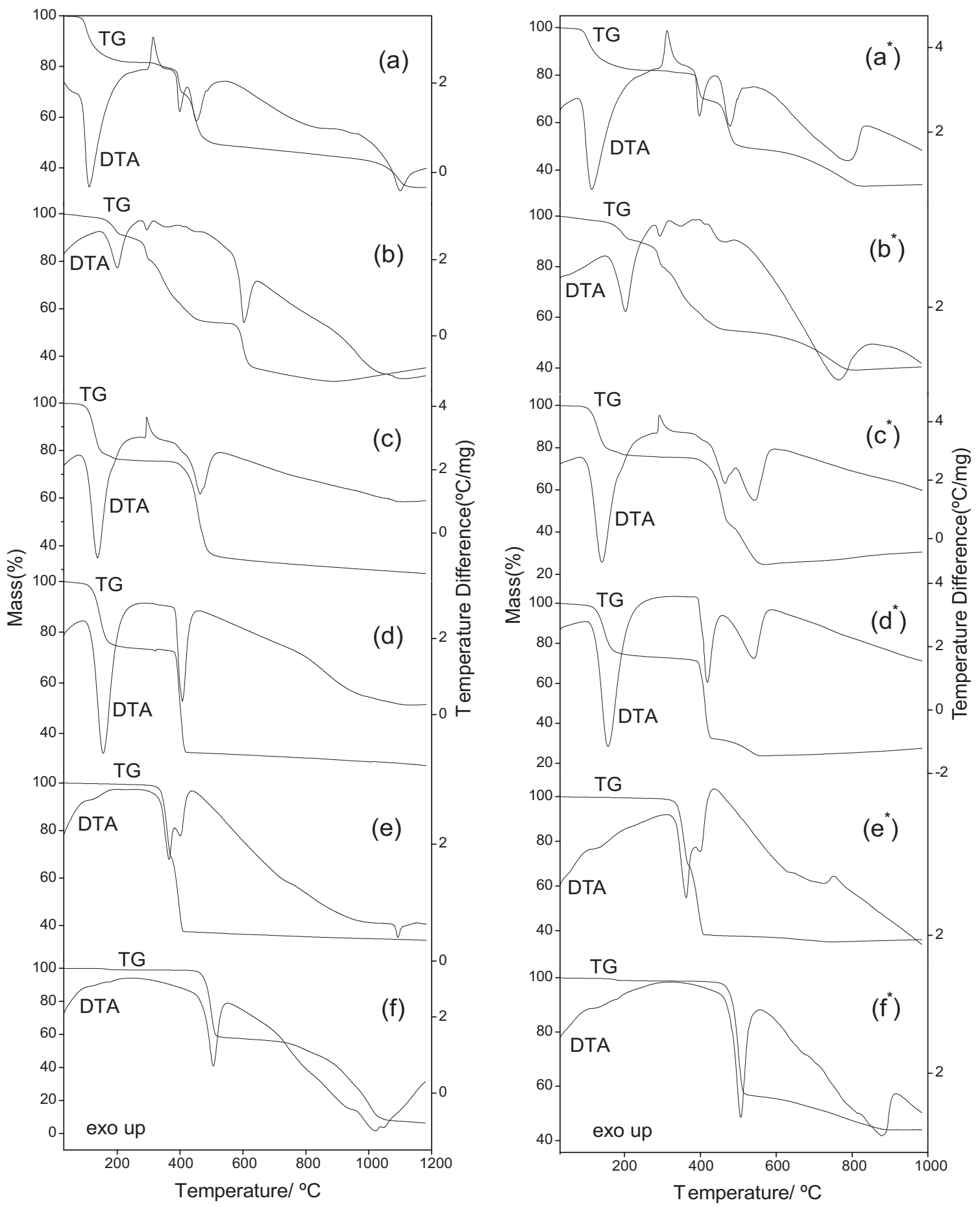

Figure 3. TG-DTA curves of the compounds in dynamic $\mathrm{N}_{2}$ and $\mathrm{CO}_{2}{ }^{*}$ atmospheres: $\left(\mathrm{a}, \mathrm{a}^{*}\right) \mathrm{MnL} \cdot 2 \mathrm{H}_{2} \mathrm{O}(\mathrm{m}=$ $7.174 \mathrm{mg} ; 7.044 \mathrm{mg} *),\left(\mathrm{b}, \mathrm{b}^{*}\right)$ FeL.1 $\mathrm{H}_{2} \mathrm{O}\left(\mathrm{m}=7.076 \mathrm{mg} ; 7.030 \mathrm{mg}\right.$ *), (c, c*) CoL.3 $\mathrm{H}_{2} \mathrm{O}(\mathrm{m}=7.066 \mathrm{mg} ; 7.135$ $\left.\mathrm{mg}^{*}\right),\left(\mathrm{d}, \mathrm{d}^{*}\right)$ NiL.3.5H2O (m=7.155 mg; $\left.7.076 \mathrm{mg} \mathrm{g}^{*}\right),\left(\mathrm{e}, \mathrm{e}^{*}\right) \mathrm{CuL}\left(\mathrm{m}=7.409 \mathrm{mg} ; 7.095 \mathrm{mg} \mathrm{g}^{*}\right)$ and (f,f*) ZnL $\left(\mathrm{m}=7.261 \mathrm{mg} ; 7.164 \mathrm{mg}^{*}\right)$. 
dehydration with loss of $2 \mathrm{H}_{2} \mathrm{O}$ (Calcd. $17.41 \%$, TG = $\left.17.70 \%(\mathrm{~N} 2), 17.35 \%\left(\mathrm{CO}_{2}\right)\right)$. The exothermic peak at $315^{\circ} \mathrm{C}$ observed in both atmospheres is attributed to the crystallization process, as shown in Fig. 4.

The thermal decomposition of the anhydrous compound in $\mathrm{N}_{2}$ atmospheres occurs in three steps between $320-410^{\circ} \mathrm{C}, 410-510^{\circ} \mathrm{C}$ and $510-1150^{\circ} \mathrm{C}$, with losses of $13.08 \%, 19.45 \%$ and $17.50 \%$, respectively, corresponding to the endothermic peaks at $400^{\circ} \mathrm{C}, 455^{\circ} \mathrm{C}$ and $1100^{\circ} \mathrm{C}$ attributed to the thermal decomposition, with formation of a mixture of $\mathrm{Mn}$ and $\mathrm{MnO}$ in no simple stoichiometric relation.

For the $\mathrm{CO}_{2}$ atmospheres, the thermal decomposition also occurs in three steps between $320-410^{\circ} \mathrm{C}, 410-505^{\circ} \mathrm{C}$ and $505-830^{\circ} \mathrm{C}$, with losses of $12.34 \%, 20.68 \%$ and $15.67 \%$, corresponding to the endothermic peaks at $400^{\circ} \mathrm{C}, 480^{\circ} \mathrm{C}$ and $790^{\circ} \mathrm{C}$ with formation of $\mathrm{MnO}$ as final residue (Calcd. $=65.74 \%, \mathrm{TG}=66.04 \%$ ).

Iron Compound. The simultaneous TG-DTA curves in $\mathrm{N}_{2}$ and $\mathrm{CO}_{2}$ atmospheres are shown in Fig. $3 \mathrm{~b}$ and $3 \mathrm{~b}^{*}$, respectively. The first mass loss between $70-215^{\circ} \mathrm{C}(\mathrm{N} 2)$ and $70-225^{\circ} \mathrm{C}(\mathrm{CO} 2)$, corresponding to the endothermic peak at $200{ }^{\circ} \mathrm{C}\left(\mathrm{N}_{2}\right)$ and 205 ${ }^{\circ} \mathrm{C}\left(\mathrm{CO}_{2}\right)$ is due to dehydration with loss of $1 \mathrm{H}_{2} \mathrm{O}$ $\left(\right.$ Calcd. $=9.49 \%, \mathrm{TG}=9.24 \%\left(\mathrm{~N}_{2}\right), 9.63 \%\left(\mathrm{CO}_{2}\right)$ ).

The thermal decomposition of the anhydrous compound in $\mathrm{N}_{2}$ atmosphere, occurs in four steps between $215-300{ }^{\circ} \mathrm{C}, 300-480^{\circ} \mathrm{C}, 565-635^{\circ} \mathrm{C}$ and $635-900{ }^{\circ} \mathrm{C}$, corresponding to the endothermic peaks at $295^{\circ} \mathrm{C}$ and $605{ }^{\circ} \mathrm{C}$, with losses of $9.25 \%$, $26.78 \%, 19.13 \%$ and $6.06 \%$, respectively. Calculations based on the mass losses observed up to $900{ }^{\circ} \mathrm{C}$, are in agreement with the formation of $\mathrm{Fe}$ (Calcd. $=70.59 \%, \mathrm{TG}=70.46 \%$ ). The mass gain (5.66\%) observed between 900 and $1180{ }^{\circ} \mathrm{C}$ is attributed to the partial oxidation of $\mathrm{Fe}$ with formation a mixture of $\mathrm{Fe}$ and $\mathrm{FeO}$. No thermal event is observed corresponding to the second and fourth mass losses, probably because endothermic and exothermic events must to occur simultaneously and the net heat or the small heat involved in these steps is insufficient to produce a thermal event.

For the $\mathrm{CO}_{2}$ atmosphere, the thermal decomposition occurs in three steps between $225-300^{\circ} \mathrm{C}, 300-$ $480^{\circ} \mathrm{C}$ and $500-800^{\circ} \mathrm{C}$, corresponding to the endothermic peaks at $295^{\circ} \mathrm{C}, 355^{\circ} \mathrm{C}, 455^{\circ} \mathrm{C}$ and $760^{\circ} \mathrm{C}$, with losses of $9.97 \%, 25.78 \%$ and $34.95 \%$, respectively. The mass losses up to $800{ }^{\circ} \mathrm{C}$, suggest the formation of a mixture of $\mathrm{FeO}$ and $\mathrm{Fe}_{3} \mathrm{O}_{4}$. The mass gain $(1.12 \%)$ observed between 800 and $980{ }^{\circ} \mathrm{C}$ is attributed to the oxidation of $\mathrm{FeO}$ with the formation of $\mathrm{Fe}_{3} \mathrm{O}_{4}$, as final residue $($ Calcd $.=59.37 \%, \mathrm{TG}=59.61 \%)$.
Cobalt Conpound. The simultaneous TGDTA curves in $\mathrm{N}_{2}$ and $\mathrm{CO}_{2}$ atmospheres are shown in Fig. $3 \mathrm{c}$ and $3 \mathrm{c}^{*}$, respectively. The first mass loss between 70 and $200{ }^{\circ} \mathrm{C}$, corresponding to an endothermic peak at $140{ }^{\circ} \mathrm{C}$, in both atmospheres is due to dehydration with loss of $3 \mathrm{H}_{2} \mathrm{O}$ (Calcd. 23.60 $\left.\%, \mathrm{TG}=23.45 \%\left(\mathrm{~N}_{2}\right), 23.29 \%\left(\mathrm{CO}_{2}\right)\right)$. The exothermic peak at $290^{\circ} \mathrm{C}\left(\mathrm{N}_{2}, \mathrm{CO}_{2}\right)$ without mass loss in the TG curve is attributed to the irreversible solid phase transition, which was confirmed by X-ray powder, with sample before and after the exothermic peak.

The thermal decomposition of the anhydrous compound in $\mathrm{N}_{2}$ occurs in two steps between $365-$ $520{ }^{\circ} \mathrm{C}$, corresponding to the endothermic peak at $465^{\circ} \mathrm{C}$ and $520-1180^{\circ} \mathrm{C}$, with losses of $41.40 \%$ and $6.90 \%$, respectively. No thermal event corresponding to the second mass loss in observed in the DTA curve, probably because the small mass loss occurs so slowly that the heat involved in this step is not sufficient to produce a thermal event. Calculations based on the mass losses up to $510{ }^{\circ} \mathrm{C}$ suggest the formation of $\mathrm{Co}_{3} \mathrm{O}_{4}$ (Calcd. $=64.69 \%, \mathrm{TG}=64.32$ $\%$ ) and up to $1180^{\circ} \mathrm{C}$ a mixture of $\mathrm{Co}$ and $\mathrm{CoO}$, in no simple stoichiometric relation.

For the $\mathrm{CO}_{2}$ atmosphere the thermal decomposition occurs in two steps between $375-480{ }^{\circ} \mathrm{C}$ and $480-575^{\circ} \mathrm{C}$, corresponding to the endothermic peaks at $470{ }^{\circ} \mathrm{C}$ and $545^{\circ} \mathrm{C}$, with losses of $32.91 \%$ and $19.17 \%$, respectively. The total mass loss up to $575{ }^{\circ} \mathrm{C}$ is in agreement with the formation of $\mathrm{Co}$ as final residue $($ Calcd. $=74.27 \%, \mathrm{TG}=74.57 \%)$. The mass gain $(5.07 \%)$ observed between $575-980{ }^{\circ} \mathrm{C}$ is attributed to the partial oxidation of $\mathrm{Co}$ with the formation of a mixture of $\mathrm{Co}$ and $\mathrm{CoO}$.

Nickel Compound. The simultaneous TGDTA curves in $\mathrm{N}_{2}$ and $\mathrm{CO}_{2}$ atmospheres are shown in Fig. $3 \mathrm{~d}$ and $3 \mathrm{~d}^{*}$, respectively. The first mass loss between $70-250^{\circ} \mathrm{C}$, corresponding to an endothermic peak at $155^{\circ} \mathrm{C}$ in both atmospheres is attributed to the dehydration with loss of $3.5 \mathrm{H}_{2} \mathrm{O}$ (Calcd. = $\left.26.51 \%, \mathrm{TG}=26.77 \%\left(\mathrm{~N}_{2}\right), 26.76 \%\left(\mathrm{CO}_{2}\right)\right)$. The thermal decomposition of the anhydrous compound occurs in two steps between $360-430^{\circ} \mathrm{C}\left(\mathrm{N}_{2}, \mathrm{CO}_{2}\right)$ and $430-1180{ }^{\circ} \mathrm{C}\left(\mathrm{N}_{2}\right)$ or $430-560{ }^{\circ} \mathrm{C}\left(\mathrm{CO}_{2}\right)$, corresponding to endothermic peaks at $405^{\circ} \mathrm{C}\left(\mathrm{N}_{2}\right)$ or $415^{\circ} \mathrm{C}$ and $540{ }^{\circ} \mathrm{C}\left(\mathrm{CO}_{2}\right)$, with losses of $41.40 \%$ and $6.90 \%\left(\mathrm{~N}_{2}\right)$ or $40.80 \%$ and $8.66 \%$, respectively. The total mass losses up to $1180{ }^{\circ} \mathrm{C}\left(\mathrm{N}_{2}\right)$ suggest the formation of a mixture of $\mathrm{Ni}$ and $\mathrm{NiO}$ and up to 560 ${ }^{\circ} \mathrm{C}\left(\mathrm{CO}_{2}\right)$ is in agreement with $\mathrm{Ni}$ (Calcd. $=75.32 \%$, $\mathrm{TG}=75.22 \%)$. The mass gain $(2.72 \%)$ observed between $560-980^{\circ} \mathrm{C}\left(\mathrm{CO}_{2}\right)$ is attributed to the partial oxidation of $\mathrm{Ni}$ to a mixture of $\mathrm{Ni}$ and $\mathrm{NiO}$. 
Copper Compound. The simultaneous TGDTA curves in $\mathrm{N}_{2}$ and $\mathrm{CO}_{2}$ atmospheres are shown in Fig. $3 \mathrm{e}$ and $3 \mathrm{e}^{*}$, respectively. These curves show that the anhydrous compound is stable up to $305^{\circ} \mathrm{C}$, in both atmospheres and above this temperature the thermal decomposition occurs in three steps. These curves also show that the first two steps occur through fast processes and overlapping one between $305-375{ }^{\circ} \mathrm{C}$ and $375-$ $420^{\circ} \mathrm{C}$, corresponding to the endothermic peaks at 365 ${ }^{\circ} \mathrm{C}$ and $400{ }^{\circ} \mathrm{C}\left(\mathrm{N}_{2}, \mathrm{CO}_{2}\right)$ with losses of $27.77 \%$ and 31.80 $\%\left(\mathrm{~N}_{2}\right)$ or $30.60 \%$ and $30.79 \%\left(\mathrm{CO}_{2}\right)$. Calculations based on the mass losses up to $420{ }^{\circ} \mathrm{C}$ suggest the formation a mixture of $\mathrm{Cu}$ and $\mathrm{CuO}$. The last step that occurs through a slow process between $420-1000{ }^{\circ} \mathrm{C}$ $\left(\mathrm{N}_{2}\right)$ or $420-750{ }^{\circ} \mathrm{C}\left(\mathrm{CO}_{2}\right)$ with losses of $0.7 \%$ and 3.15 $\%$, respectively, is attributed to the reduction of the mixture $(\mathrm{Cu}, \mathrm{CuO})$ to $\mathrm{Cu}$, as final residue $(\mathrm{Calcd} .=64.22$ $\%, \mathrm{TG}=64.48 \%\left(\mathrm{~N}_{2}\right), 64.54 \%\left(\mathrm{CO}_{2}\right)$. The endothermic peak at $1090^{\circ} \mathrm{C}\left(\mathrm{N}_{2}\right)$ is due to the fusion of $\mathrm{Cu}$.

Zinc Compound. The simultaneous TG-DTA curves in $\mathrm{N}_{2}$ and $\mathrm{CO}_{2}$ atmospheres are shown in Fig. $3 \mathrm{f}$ and $3 \mathrm{f}^{*}$, respectively. These curves show that the anhydrous compound is stable up to $430^{\circ} \mathrm{C}$ and above this temperature the thermal decomposition occurs in two steps between $430-535^{\circ} \mathrm{C}$ and $535->1080^{\circ} \mathrm{C}\left(\mathrm{N}_{2}\right)$ or $430-525^{\circ} \mathrm{C}$ and $525-885\left(\mathrm{CO}_{2}\right)$, corresponding to the endothermic peaks at $505^{\circ} \mathrm{C}, 1020^{\circ} \mathrm{C}$ and $1050^{\circ} \mathrm{C}(\mathrm{N} 2)$ or $505^{\circ} \mathrm{C}$ and $885^{\circ} \mathrm{C}\left(\mathrm{CO}_{2}\right)$, with losses of $40.10 \%$ and $51.95 \%\left(\mathrm{~N}_{2}\right)$ or $41.88 \%$ and $13.08 \%\left(\mathrm{CO}_{2}\right)$.

For the $\mathrm{CO}_{2}$ atmospheres the mass lost up to $885^{\circ} \mathrm{C}$ is in agreement with the formation of $\mathrm{ZnO}$ as final residue $($ Calcd. $=55.16 \%, \mathrm{TG}=54.95 \%)$. For the $\mathrm{N}_{2}$ atmospheres in the last step occurs the reduction of $\mathrm{Zn}$ (II) to $\mathrm{Zn}$ followed by ebullition (boiling point $=907$ $\left.{ }^{\circ} \mathrm{C}\right)$. The final residue $(7.95 \%)$ up to $1080{ }^{\circ} \mathrm{C}$ is attributed to the carbonaceous residue, which was confirmed after to analysis the crucible residue.

The mass gain attributed to the oxidation reaction of Fe to $\mathrm{FeO}$ in $\mathrm{N}_{2}$ atmosphere or $\mathrm{Co}$ to $\mathrm{CoO}$ and $\mathrm{Ni}$ to $\mathrm{NiO}$ in $\mathrm{CO}_{2}$ atmosphere occurs, probably because the equipment is not hermetically sealed and/or a trace of oxygen in the $\mathrm{N}_{2}$ or $\mathrm{CO}_{2}$ which were used as purge gas.

\section{Evolved gas analysis}

The gaseous products evolved during the thermal decomposition in dynamic nitrogen atmosphere of the sodium and transition metal ion compounds studied in this work were monitored by FTIR and identified on basis of their FTIR references available on Nicolet libraries. For the sodium succinate the gaseous products evolved during a thermal decomposition were identified as methane, acetone, $\mathrm{CO}$, and

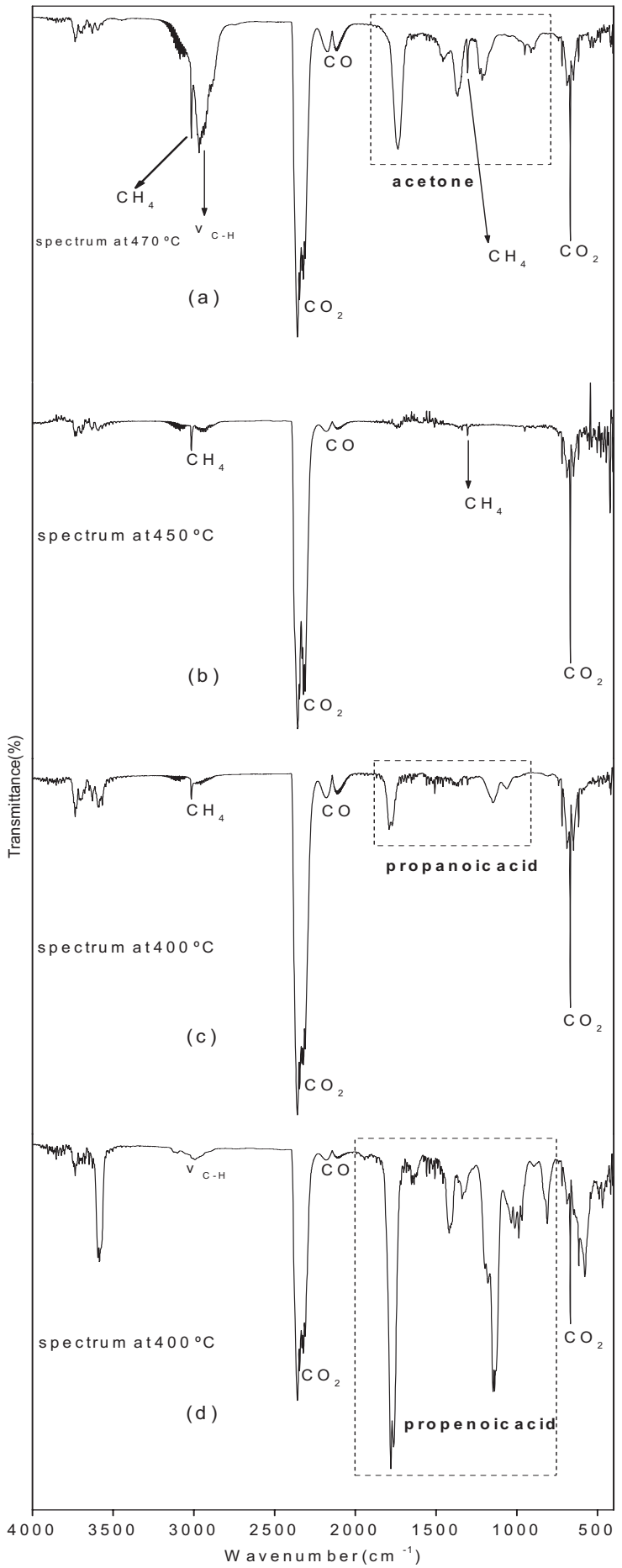

Figure 4. IR spectra of gaseous products evolved during the decomposition of the compounds in nitrogen atmosphere: (a) NaL. $6 \mathrm{H}_{2} \mathrm{O}$, (b) $\mathrm{MnL} \cdot 2 \mathrm{H}_{2} \mathrm{O}$, (c) NiL. $3.5 \mathrm{H}_{2} \mathrm{O}$ and (d) CuL. ${ }^{\mathrm{L}=\text { succinate }}$ 
$\mathrm{CO}_{2}$; for the cobalt and nickel compounds were methane, propanoic acid, $\mathrm{CO}$, and $\mathrm{CO}_{2}$; for the copper compound were propenoic acid, $\mathrm{CO}$, and $\mathrm{CO}_{2}$ and for the manganese, iron, and zinc compounds were methane, $\mathrm{CO}$ and $\mathrm{CO}_{2}$. The IR spectra of the gaseous products evolved during the thermal decomposition of sodium, manganese, nickel and copper as representative of other compounds, are shown in Fig. 4.

\section{Conclusion}

The present study showed that the succinic acid melt and evaporate, without decomposition.

In the sodium and all the synthesized compounds, the evolved products during the thermal decomposition in nitrogen atmosphere was $\mathrm{CO}$ and $\mathrm{CO}_{2}$, besides methane and acetone for sodium succinate, propanoic acid for cobalt and nickel compounds and propenoic acid for nickel compound.

\section{Acknowledgements}

The authors thank FAPESP, CAPES and CNPq foundations (Brazil) for financial support.

Resumo: A estabilidade e a decomposição térmica do ácido succínico, succinatos de sódio, Mn(II), Fe(II), $\mathrm{Co}(\mathrm{II}), \mathrm{Ni}(\mathrm{II}), \mathrm{Cu}$ (II) e $\mathrm{Zn}$ (II) foram investigados empregando termogravimetria e análise térmica diferencial simultânea (TG-DTA) em atmosferas de nitrogênio e dióxido de carbono e TGFTIR em atmosfera de nitrogênio. Sobre aquecimento em ambas as atmosferas o ácido succínico funde e evapora, enquanto para o succinato de sódio a decomposição térmica ocorre com a formação de carbonato de sódio. Para os succinatos de metais de transição o resíduo final até $1180^{\circ} \mathrm{C}$ em atmosfera de $\mathrm{N}_{2}$ foi uma mistura de metal e óxido de metal sem relação estequiométrica, exceto para o composto de zinco, onde o resíduo foi uma pequena quantidade de resíduo de carbono. Para a atmosfera de $\mathrm{CO}_{2}$ o resíduo final até $980^{\circ} \mathrm{C}$ foi: $\mathrm{MnO}, \mathrm{Fe}_{3} \mathrm{O}_{4}, \mathrm{CoO}, \mathrm{ZnO}$ e misturas de $\mathrm{Ni}$, NiO e $\mathrm{Cu}, \mathrm{Cu}_{2} \mathrm{O}$.

\section{References}

[1] H. Yokobayashi, K. Nagase, K. Muraishi, Bull. Chem. Soc. Jpm. 48 (1975) 2789.

[2] J. R. Allan, B. R. Carson, Thermochim. Acta 158 (1990) 91.

[3] Y. Suzuki, Thermochim. Acta 255 (1995) 155.

[4] W. Brzyska, B. Galkowska, Polish J. Chem. 72 (1998) 498.
[5] A. K. Nikumbh, S. K. Pardeshi, M. N. Raste, Thermochim. Acta 374 (2001) 115.

[6] B. S. Randhawa, K. Gandotra, J. Therm. Anal. Cal. 85 (2006) 417.

[7] F. J. Caires, L. S. Lima, C. T. Carvalho, M. Ionashiro, Thermochim. Acta (2009). In Press., doi: 10.1016/j.tca.2009.11.015.

[8] C. N. de Oliveira, M. Ionashiro, C. A. F. Graner, Ecl. Quim 10(1985) 7. 
